\title{
Developing Professional Skills
}

\section{in Pre-primary Teachers via Reflexion and Self-Reflection}

\author{
Zora Syslová, Nina Ziklová
}

\begin{abstract}
This study brings for discussion on pre-primary education the view upon developing reflective skills of students of pre-primary teaching as well as using self-reflection in the work of kindergarten teachers. The authors talk in the introduction to the study about reflection as in teaching as the key factor in the professional growth in both the preservice teachers as well as the in-service teachers. They are presenting the information on the state of the art findings in this field. The key part of the text is devoted to action research within which the video recording of the teacher's own work was used and reflected upon subsequently (reflection on action). Analysing and evaluating one's own work brings the teacher information on the positive moments of his/her approaches, on the education management as well as on the critical moments of the educational reality. In the conclusion of the study the authors reflect upon the possibilities of action research in connection with developing reflective skills as well as its use in implementing more effective educational strategies in pre-primary education.
\end{abstract}

Key words: reflection, self-reflection, kindergarten teacher, student, pre-service teacher training, professional development. 


\section{Introduction}

In the recent years the Czech Republic has been facing increasing interest in pre-primary education (Kropáčková, Janík, 2014; Strategie 2020), which is opening the discussion regarding the professionalisation of kindergarten teachers (Wiegerová et al., 2015, p. 12). University education seems to be the inevitable qualification prerequisite for becoming a pre-primary education teacher (Helus, 2014; Oberhumer, Schreyer, \& Neuman, 2010).

The world witnesses the enforcement of the reflective model of teacher training education or so-called realistic approach in teacher training (Korthagen et al., 2011). "The starting point being the conception of a teacher as a reflective practitioner, who thinks in depth about his/her activities, analyses and evaluates it in the relationship to the planned objectives to be able to modify his/her teaching strategies and methods and to propose alternatives" (Spilková et al., 2015, p. 8).

The theoretical and research discourse more and more frequently focuses on the reflective skills of teachers both in Czech as well as foreign pedagogical literature. A team of Spanish and Dutch authors (Marcos \& Tillema 2006), who carried out metaanalysis of texts dealing with the said subject matter pointed out that majority of such studies were focusing upon determining the level or type of reflection (e.g. Hatton \& Smith, 1995; Mezirow, 1997; Zeichner \& Liston, 1996), or ways of thinking (King \& Kitchener, 1994; Baxter 2004), however, only a few of those studies provide information on the conduct of reflection and its use for improving the teaching practice.

The above stated facts led the authors of the current study to their aim to introduce the action research of a student of the life-long study programme of teacher training for kindergarten teachers. The stated research was based upon reflection over the video recording of her own work. The results show how the individual steps were helping the student to realise the critical moments of education and to find more effective ways of implementation.

\section{Theoretical background}

The discussions regarding the professionalisation of teaching profession calls upon the need of change in the curriculum of the pre-service teacher training in the direction to the reflective practitioner.

The development of reflective thinking can be designated as a cumulative process (Fig. 1), in which the individual is consciously researching his/her own personal experience gained in the teaching practice, is dividing them into partial steps, is searching for connections and is substantiating them.

The evaluation of the educational results, professional decisions and the subsequent discussion about them are, therefore, becoming an important part of the tuition 
of pre-service teachers (Pollard et al., 2008). This is the only way for the students to learn "via their own experience and from their experience with the aim of gaining new understanding of oneself and/or the practice" (Píšová et al., 2011, p. 43). The reflection is becoming a building stone of the professional development of teachers as a basis for the continuous professional learning (Finlay, 2008; Hatton \& Smith, 1995; Schön, 1987; Korthagen et al., 2011; Shulman, 1987), which is starting in the pre-service education (La Boskey, 1993).

Figure 1

The process of developing reflective skills

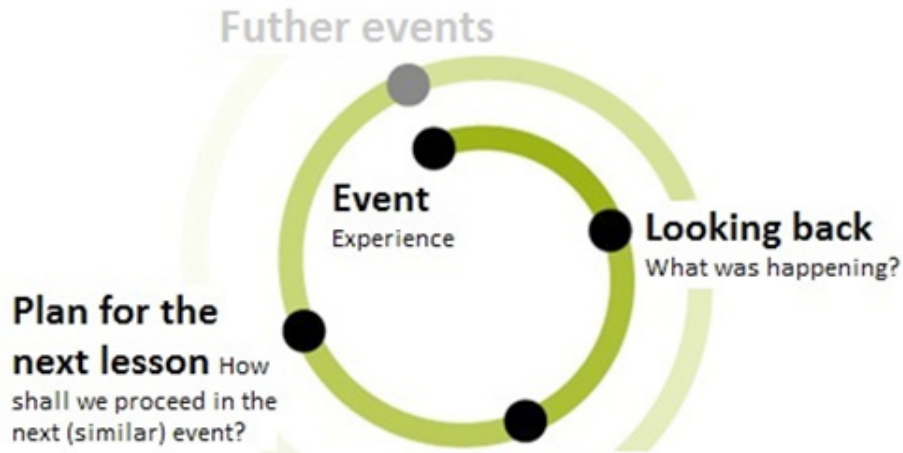

Evaluation

What have we done well? What was not going well?

There are more reflective models and they differ mainly in the viewpoint upon the individual phases. Some authors look upon reflection by the prism of questions, which are asked (Smyth, 1989), some through the cognitive operations, which are taking place in reflection (Píšová, 2005). The most famous is the Korthagen's ALACT model (2011, p. 58).

Due to the fact that observing video recordings is becoming an integral part of education at the faculties that are preparing pre-service kindergarten teachers (Horká, Syslová, \& Grůzová, 2014; Navrátilová, 2015), it is inevitable to focus upon the standpoint of the process and to ask questions, which are inviting us to deeper analytic work. Mere looking at a video recording enables one to catch the sight of only external aspects of the pedagogical phenomena, however, it does not lead to any deeper understanding of them.

One of the possibilities is the use of the hierarchy of questions according to their cognitive sophostication, as stated in Janík and Miková (2006, p. 118). The first level of 
questions is aiming at the description of what can be seen and heard in the video recording. The second level of questions is dealing with feelings and the sense of what has been recorded. The third level of questions is searching for the meaning of the acting of the people in the video recording. The fourth level of questions is related to searching for new solutions, alternatives of the situations recorded in the video recording. These questions became an integral part of the design of the action research presented in this study.

The research studies of reflection in pre-school teachers are quite rare (Pihlaja \& Holst, 2013; Syslová \& Hornáčková, 2014). The results show that frequently the level of reflection is only on the technical or practical level, and only in minimum rate it reaches the critical level (Syslová, 2015). On the technical level it is usually the description of the work, which is connected to the question "What is happening?" On the practical level there are evaluations regarding the fact what is or is not right. On this level the questions and answers regarding what and how it is happening are sought. On the critical level the answers are given regarding the questions of what, how, and why it is happening. It is the analysis of the phenomena in connection with the social context or with scientific theories (Farrell, 2004; Van Manen, 1977).

Higher level of cognitive operations can be seen in the kindergarten teachers who have reached higher (i.e. university) qualification. The professional skills of these teachers are directed to the "anticipation of the events occurring in the classroom as well as more long-term planning (in a wider context) supported by the analysis of real situations" (Syslová, Hornáčková, 2014, p. 556).

\section{Methods}

The aim of the action research was to find out, if and how the teacher supports the children's learning in harmony with the constructivist approach. To fulfil the aim we have chosen the criteria from the evaluation tool "Framework of profession qualities of kindergarten teacher" (Syslová, Chaloupková, 2015). The set out criteria were projected into the well-arranged record sheet, which served for the record of the ascertained situations including the time of the occurring situation, which facilitated the orientation in the recording.

The action research was conducted by a life-long student of the teacher training programme for kindergarten teachers, who had been working in a kindergarten. The research was conducted within the framework of her final work. In action research the researcher, in our case a kindergarten teacher, focuses on the acting - action with the aim to increase its effectivity. Action research was accurately described by Pavelková (2012, p. 8): "Action research is trying to bridge the gap between the theory and the practice. While the academic research results influence practice only in a limited way, action research is a suitable tool how research results can be transferred into practice 
and thus speed up the process of needed changes." Action research is formed by three components: action, research, and formative. It is not only a detailed description of the situation, however, it is the analysis and the subsequent intervention as well as implementing the proposed measures. It is a cyclic process within which permanent reflection is taking place regarding new findings, and reactions upon the situation in the classroom. The formative effects are shown in the changes of the relationships in the group but also in the changes in the attitudes and values of the individual participants. In the case of pre-primary education it means the changes in the relationships of the teacher and the children, but also among the children themselves.

The concrete selection of the monitored aspects fundamentally changed the viewpoint upon the whole recording from the mere unaimed observation and description of events to systematic discovering and realising the individual situations, their evaluation to the consideration of possible changes.

The video recording was taken in May 2015 in a kindergarten in Hradec Králové in a heterogeneous classroom with 24 children. It shows the activities connected with their water project. The teacher gained the written consent for the video recording from all the legal representatives from all the children in the recording. The recording lasted approximately 13 minutes and was taken by a teacher, who is working in the classroom with the student conducting the research. The recorded activity shows preparation of "ice brushes". In terms of organisation the activity was planned as group work. The groups were to be created from the children according to a selected criterion. In the next step the teacher is explaining the work procedure to the children. Before starting the activity itself the children together with the teacher are determining the rules for managing it, followed by the offer of the needed tools and material. The children are choosing and preparing their workplace themselves. The children are starting to work in group, they are working independently, the teacher is monitoring them, she is walking around the groups, asking children, how they were involved in the preparation of the colours, she stops at a group of boys and by asking questions she is aiming at solving a problem that came into being in that group. The recording finishes by the children washing their hands.

The work with the video recording was carried out in the subsequent steps as described by Janík and Miková (2006, p. 118): (1) Description of the video recording, taking down the first impressions, (2) Analysis of the recording on the basis of the selected criteria, (3) Discovering the causes of critical moments (4) Searching for possibilities how to make the children's education more effective. 


\section{Findings}

Then analysing the video recording al, the above stated levels of question according to Janíka and Miková were kept (2006). Subsequently, the findings have been structured according to those stated levels.

\subsection{Description of the educational reality}

The first level comprised of a very detailed description of all that one could see and hear in the recording. This detailed written description helped to uncover hidden moments, which would have probably stayed unnoticed if watched only ones. We are included part of the description to illustrate the aforesaid as the whole description is 3 pages of text.

I am speaking to the children who are sitting in a semicircle on the carpet and I am in a semi-squat facing them. I am telling them what they are going to do in the following moments. They are learning that they will, themselves, make ice colours, and I am holding a bowl with ice. I am telling them that tomorrow we are going to become ice painters. One boy is telling me with sorrow that he is not going to be in the class tomorrow. I am asking: How come?", he is answering, that he will go to Trutnov and has to repeat it to me as I do not understand. I am telling him that we are going to speak to him about it and that we will show him the pictures that we will paint with the ice colours tomorrow. He nods in agreement. I am explaining to him that he is in the class today and that he is important. He is nodding and he is content...

\subsection{Analysis of the video recording}

The second step was the analysis of the individual parts of the video recording. First, the situations fulfilling the set criteria were looked for (see the extract from table 1). 
Table 1

The record sheet for fulfilling the set criteria arch

\begin{tabular}{|l|l|l|l|}
\hline Criterion & $\begin{array}{l}\text { FULFILLED } \\
\text { YES/NO }\end{array}$ & $\begin{array}{l}\text { A brief description of the situation in which the set } \\
\text { criterion is fulfilled }\end{array}$ & $\begin{array}{l}\text { Time } \\
\text { The concrete time } \\
\text { in the video recording }\end{array}$ \\
\hline Teach by experience & YES & $\begin{array}{l}\text { The children are experimenting with water and food } \\
\text { colouring, they are adding colour into water or the other } \\
\text { way round, they are mixing the colours, they are observing } \\
\text { the way the colours are diluting. }\end{array}$ & $\begin{array}{l}9: 50 \\
11: 04\end{array}$ \\
\hline $\begin{array}{l}\text { Determine and keep } \\
\text { rules together with the } \\
\text { children }\end{array}$ & YES & $\begin{array}{l}\text { The children are asked to determine the rules for the work } \\
\text { with water and colours, work in groups. }\end{array}$ & $5: 21$ \\
\hline Give concrete feedback & YES & $\begin{array}{l}\text { I am giving children negative feedback that one of the } \\
\text { groups is not fulfilling the set criteria - there is no pre- } \\
\text { schoolar. } \\
\text { I am reassuring Karolínka, that she has managed her task } \\
\text { and to be sure l am explaining the function of the stick put } \\
\text { though the cardboard stripe. }\end{array}$ & $\begin{array}{l}2: 45 \\
3: 11 \\
9: 25\end{array}$ \\
\hline
\end{tabular}

After that the teacher was going through the video recording several more times and she found out that she was using a lowered position when communicating with the children, which brings the feeling of being closer to the children (0:11), she is showing empathy and she is helping a boy who has a problem to find the solution to his situation (0:23), she is giving the children space for solving the problem and for their own choices (8:32), she is trying to be consistent, i.e. if the conditions for a certain activity have not been fulfilled, the next activity could not start (3:05), she is training to respect the proposals of children: it was the situation of mixing the colours, first I am hesitating, then I am admitting this possibility under certain conditions, and I am glad, that the children came up with their own idea (9:07). She is paying her attention to the groups individually being interested what each child has tried (10:56).

\subsection{Alternative proposals}

Whem analysing the videorecording there are also critical moments and situations that the teacher would like to solve and change in the future. Above the list of all the positive as well as critical moments there is the beginning of thinking over the causes of their coming to existence, why it took place the way it did, why it happened - which is the third level of the questions. It is usual that questions are answered. Questions led me to creating a plan for improvement, for proposing a completely different way os management that gives the child space to activate his/her thinking and fulfils the essence of experiential learning. 
The teacher has noticed that the word "so" has been used very often. She said, "even I was disturbed by it when watching the recording." It is probably a parasitic word, i.e. an overused word, which has no syntactic relation to the content of the communication. Furthermore, she noticed that when setting the management task: "Create four groups in such a way that there is at least one pre-schooler", she used a condition, which was not later used in the activity and, moreover, she confused the children with the concept of "at least" by which she unnecessarily lengthened the time of forming the groups (00:40). The children were given space to choose any member for their groups, she, the teacher, was subcounsciously putting the pre-schooler into the position of a group leader, which was unnecessary, eventually it seemed that the given condition was even to the detriment as the oldest pre-schoolers wanted to do majority of the activities on their own and smaller children thus did not have the access to try the experiment.

She found out that she was repeating the instructions several times (3:31, 3:52, $4: 13,7: 05)$. I have realised that it is important to eliminate the excess of one's own management and let the children have enough space and time, I will be using my information and instructions in a more thought up way, briefly, loud enough, emphatically, and only once.

She is completely unnecessarily and often expressing her fears of damaging the furnishing of the classroom or the children's clothes $(4: 06,5: 29,6: 12,7: 37,8: 25)$. I have found the cause of my fear of making the carpet or the children dirty, firstly it is my own experience of a mother, and, secondly, the unpleasant experiences I have had with some parents. My worries regarding the damaging of the furnishings or children's property can be avoided by using protective equipment, adjust the workplace to the planned activity, at the meeting wth the parents at the beginning of the school year I will introduce the parents with the fact that if their children are to discover the world with joy, neither the children or the teacher should be tied with the fear that they might, not on purpose, make their new T-shirt dirty. I will ask the parents to give their children "work" clothes to the kindergarten to make the worries of being reprimanded disappear. I will also focus on a more frequent use of "I" statements, giving concrete description of situations and using feedback towards the group as well as the individual children.

Regarding further critical findings there were, for example: I talk to much, I am not giving the children enough opportunities and the whole activity seems too organised and takes too long. The said findings led me to critical thinking and the subsequent looking for the causes of the situation that took place. I found myself that I have the tendency to keep explaining everything to the children because I think that they cannot know it.

The subsequent step led to proposing the concrete improvements. Next time it would be suitable to plan the education a bit differently. The introductory motivation part would be kept. I would ask the children what we would need for making the ice brushes. Then there would be a thinking time over the risks of the future activity and the children would be formulating the rules themselves. It would be mainly the children who would be thinking and talking. The next step would be creating groups according to a set criterion 
(the best would be according to the available equipment). Then there would be the preparation of the material and the workplace organised by the children themselves, the teacher would only facilitate the sufficient amount of tools and material. Then the children would be working completely on their own. They would be choosing the procedure in their groups, they would be discussing, discovering ...

When thinking over the changes in the working with the children, the teacher was leaning against the requirements for the pre-primary education. For example, the groups should have the opportunity to present their results, or the ways how they reached them, to the other groups. I think that such a planned activity would be fulfilling all the criteria of experiential learning.

Some proposals for changes were not resulting from any negative evaluation but from the theoretical knowledge. For example, I would like to observe more such situations that would deserve verbal assessment. Appraisal is the best motivation to further activity. When formulating appraisals I will be using concrete feedback to the child as much as possible.

\section{Results}

In the first moments of watching the video recording one has the tendency to watch mainly oneself, also what prevails are the impressions of shallow nature. He/she is not looking at the interactions with the surroundings, which is why it is necessary to leave this approach as soon as possible. Such a viewpoint could cast a shadow even upon very important and for further practice needful findings. It is beneficial to focus on the overall influence of one's personality upon the environment, i. e. how the children view us, if we act positively or sadly, defensively or unsure, if we talk quickly or slowly and understandably, aloud or silently.

The statements of the student showed that when analysing the video recording she had been gradually discovering more and more interesting situations, gradually she stopped being interested in her own person and started watching more the reactions of the children, how they react to the teacher, in what interactions they are among themselves, how they are interested or uninterested by the activity. I think that the video recording could be a good tool for pedagogical diagnostics. The repeated observation of the recording enabled me to notice and ascertain many a positive as well as negative moments. When observing the video recording I was living through the recorded activity again but now step by step. Twice, three times ... ten times ... I saw many things, which I would not be able to notice in the real time. I was playing the video recording over and over again and was discovering new realities. It is the possibility to repeatedly observe the objective reality and continuously analyse it what makes this self-reflection tool unique. 
The whole analysis of the recording enabled the teacher to have a critical look at her own teaching activity, it led her to thinking over the effectivity of her work as well as to looking for better solutions. She realised that the skills needed for self-reflection have to be worked upon all the time to improve them.

\section{Conclusion}

The above stated findings lead to considering the fact that video camera can become a good aid in thinking on the professional skills of teachers. It is the silent scrivener who does not evaluate, does not criticise and lets the person to see themselves in action. The video recording as a tool for the development of reflective skills enables to open the door to a better professional self-cognition. It gives the opportunity to repeated observation of the educational situation. We can analyse it into the tiniest details, we can return to the individual moments as many times as we want, it activates our thinking, it forces us to look for connections and causes. It provokes us to searching for more effective solutions of similar situations. It teaches us to view oneself critically in the relationship to the educational process. It leads us to the professional improvements. It is important that each teacher stayed open to the changes occurring in the teaching profession as only in that way her professional competences can develop.

The question is how to start the non-ceasing process of self-awareness, self-evaluation and self-actualisation. One of the answers could be creating electronic educational environment, which uses video recordings from real lessons in the combination with questions and tasks (Minaříková, Janík, 2012, p. 199), and so provide the students with the support in observing and reflecting of "another person's teaching" mediated by the video recording and thus supporting the development of professional vision. If a student is able to see the important aspects of education, he/she can improve reflecting upon his/her own practical experience (Syslová et al., 2014, p. 26).

Even though we trust in the potential of such pre-service teacher training, it seems to be necessary, to subdue the efficacy of work with video recordings to further research.

\section{References}

Baxter, M., B. (2004). Evolution of a constructivist conceptualization of epistemological reflection. Educational Psychologist, 39(1): 31-42.

Farrell, T., S. (2004). Reflective practice in action: 80 reflective breaks for busy teachers. Thousand Oaks, CA: Corwin Press.

Finlay, L. (2008). Reflecting on 'Reflective practice'. Practise-based profesional learning cebtre. [on-line] retrieved from: http://www.open.ac.uk/cetl-workspace/cetlcontent/documents/ 4bf2b48887459.pdf 
Hatton, N. \& Smith, D. (1995). Reflection in teacher education: towards definition and implementation. Teaching and Teacher Education, 11(1): 33-49.

Helus, Z. (2014). K psychologii láskyplného vztah: Pedagogické inspirace se zaměřením na předškolní pedagogiku. Pedagogická orientace, 24(4): 468-487.

Horká, H., Syslová, Z. \& Grůzová, L. (2014). Reflexe zkušeností studentů v prípravném vzdělávání učitelů mateřských škol. ACORát, 3(1): 3-9. [on-line] retrieved from: http://www.acor.cz/Studovny/casopis-ACORat.aspx

Janík, T. \& Miková, M. (2006). Videostudie: výzkum výuky založený na analýze videozáznamu. Brno: Paido.

King, P. M. \& Kitchener, K. S. (1994). Developing reflective judgment. San Francisco: Jossey-Bass Publishers.

Korthagen, F., et al. (2011). Jak spojit praxi s teorii: didaktika realistického vzdělávání učitelů. Brno: Paido.

Kropáčková, J., Janík, T. (2014). Editorial: Předškolní pedagogika - etablování oboru. Pedagogická orientace, 24(4): 465-467.

La Boskey, V., K. (1994). Development of reflective practise: A study of preservice teachers. New York and London: Copyright by teachers College, Columbia University.

Marcos, M. J., \& Tillema. H. (2006). Studying studies on teacher reflection and action: An appraisal of research contributors. Educational Research Review, 2(1): 112-132.

Mezirow, J. (1997). Transformative Learning: Theory to Practice. New Directions for Adult and Continuing Education, 74(1): 5-12.

Minaříková, E., \& Janík, T. (2012). Profesní vidění učitelů: od hledání pojmu k možnostem jeho uchopení. Pedagogická orientace 22(2): 181-204.

Navrátilová, H. (2015). Učitel/ka mateřské školy a jeho postavení ve školském systému. In Wiegerová, A. et al. Profesionalizace učitele mateřské školy z pohledu reformy kurikula. Zlín: Univerzita Tomáše bati ve Zlíně, Fakulta humanitních studií.

Oberhuemer, P., Schreyer, I., \& Neuman, M. J. (2010). Professionals in early childhood education and care systems. European profiles and perspectives. Opladen \& Farminghton Hills: Barbara Budrich.

Pavelková, A. (2012). Akční výzkum v pedagogickém prostředí. Diplomová práce. Brno: Masarykova univerzita, Filozofická fakulta, Ústav pedagogických věd. Vedoucí práce Mgr. Roman Švaříček, Ph.D.

Pihlaja, M. P. \& Holst, T. K. (2013). How Reflective are Teachers? A Study of Kindergarten Teachers' and Special Teachers' Levels of Reflection in Day Care. Scandinavian Journal of Educational Research, 57(2): 182-198.

Píšová, M. (2005). Klinický rok: Procesy profesního rozvoje studentů učitelství a jejich podpora. Pardubice: Univerzita Pardubice.

Píšová, M. et al. (2011). Teorie a výzkum expertnosti učitelské profese. Brno: Muni Press.

Shulman, L. B. (1987). Knowledge and teaching: Foundations of the New Ref. Harvard Educational Review, 57(1): 1-22.

Schön, D., A. (1987). Educating the reflective practitioner: toward a new design for teaching and learning in the professions. San Francisco: Jossey-Bass.

Smyth, J. (1989). Developing and Sustaining Critical Reflection in Teacher Education. Journal of Teacher Ecucation, 40(2): 2-9.

Spilková, V., Tomková, Mazáčová, N., Kargerová, J., et al. (2015). Klinická škola a její role ve vzdělávání učitelů. Praha: Retida.

Svojanovský, P. \& Švec, V. (2014). Sebereflexe jako pomocník učitele. [on-line] retrieved from: http:// karsysped.ped.muni.cz/skolni-pedagogika/pro-zacatecniky/sebereflexe-jako-pomocnik-ucitele/

Syslová, Z. (2015). The level of reflection in the professional development of pre-primary teachers. Przeglad Pedagogczny, 9(1): 73-84. 
Syslová, Z., Horká, H. \& Lazarová, B. (2014). Od teorie předškolního vzdělávání k praxi v mateřské škole. Brno: PdF MU.

Syslová, Z. \& Hornáčková, V. (2014). Kvalita reflexe v profesním myšlení učitelek mateřských škol. Pedagogická orientace, 24(4): 535-561.

Syslová, Z. \& Chaloupková, L. (2015). Rámec profesních kvalit učitele mateřské školy. Brno: Masarykova univerzita.

Pollard, A., Anderson, J., Maddock, Swaffield, S., Warin, J. \& Warwick, P. (2008). Reflective teaching 3th edition: Evidence-informed professional practice. London: Continuum.

Van Manen, M. (1995). On the epistemology of reflective practice. Teachers and Teaching:Theory and Practice, 1(1): 33-50.

Wiegerová, A., et al. (2015). Profesionalizace učitele mateřské školy z pohledu reformy kurikula. Zlín: Fakulta humanitních studií UTB.

Zeichner, K. \& Liston, D. (1996). Reflective Teaching: an introduction. Mahwah, New Jersey: Lawrence Erlbaum Associates.

Ziklová, N. (2015). Profesionalita učitele mateřské školy. Závěrečná práce. Brno: Masarykova univerzita, Pedagogická fakulta, Katedra primární pedagogiky. Vedoucí práce: PhDr. Zora Syslová, Ph.D.

\section{Contact:}

PhDr. Zora Syslová, Ph.D.

Faculty of Education, Masaryk University, Poříčí 31, 60300 Brno, Czech Republic

E-mail: syslova@ped.muni.cz

Mgr. Nina Ziklová

The Kindergarten Podzámčí, Hradec Králové, Svatojánská 680/15, 50011 Hradec Králové, Czech Republic

E-mail: ninaziklova@seznam.cz 